\title{
Gut commensal Bacteroides acidifaciens prevents obesity and improves insulin sensitivity in mice
}

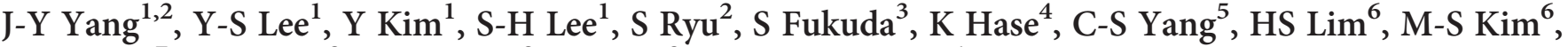 \\ $\mathrm{H}-\mathrm{M} \mathrm{Kim}{ }^{7}, \mathrm{~S}-\mathrm{H} \mathrm{Ahn}{ }^{8}, \mathrm{~B}-\mathrm{E}$ Kwon ${ }^{9}, \mathrm{H}-\mathrm{J} \mathrm{Ko}{ }^{9}$ and M-N Kweon ${ }^{1}$
}

In humans, the composition of gut commensal bacteria is closely correlated with obesity. The bacteria modulate metabolites and influence host immunity. In this study, we attempted to determine whether there is a direct correlation between specific commensal bacteria and host metabolism. As mice aged, we found significantly reduced body weight and fat mass in $A \operatorname{tg} 7^{\Lambda \mathrm{CD} 11 \mathrm{C}}$ mice when compared with $A \operatorname{tg} 7^{\mathrm{t} / \mathrm{f}}$ mice. When mice shared commensal bacteria by cohousing or feces transfer experiments, body weight and fat mass were similar in both mouse groups. By pyrosequencing analysis, Bacteroides acidifaciens (BA) was significantly increased in feces of $A \operatorname{tg} 7^{\mathrm{ACD} 11 \mathrm{c}}$ mice compared with those of control $A \operatorname{tg} 7^{f / f}$ mice. Wild-type C57BL/6 (B6) mice fed with $B A$ were significantly more likely to gain less weight and fat mass than mice fed with PBS. Of note, the expression level of peroxisome proliferator-activated receptor alpha $(P P A R \alpha)$ was consistently increased in the adipose tissues of $A \operatorname{tg} 7^{\mathrm{ACD11C}}$ mice, B6 mice transferred with fecal microbiota of $A \operatorname{tg} 7^{\Lambda \mathrm{CD} 11 \mathrm{c}}$ mice, and $B A$-fed $\mathrm{B} 6$ mice. Furthermore, B6 mice fed with $B A$ showed elevated insulin levels in serum, accompanied by increased serum glucagon-like peptide-1 and decreased intestinal dipeptidyl peptidase-4. These finding suggest that $B A$ may have potential for treatment of metabolic diseases such as diabetes and obesity.

\section{INTRODUCTION}

Obesity is linked worldwide to type 2 diabetes, cardiovascular disorders, cancer, and asthma. ${ }^{1}$ Trials to assess potential obesity treatments are complicated by life styles and genetic polymorphisms; however, energy imbalance is an obvious cause. ${ }^{2}$ Therefore, many scientists have sought environmental factors that influence energy balance.

Autophagy, the self-digesting pathway, is best known as an innate adaptation to starvation. ${ }^{3}$ Its mechanisms have indispensable roles in the maintenance of host homeostasis by removing misfolded proteins and damaged organelles. ${ }^{4}$ In recent years, autophagy has been implicated in several pathological and physiological conditions including infectious and autoimmune diseases, cancer, and metabolic disorders that include obesity. ${ }^{5}$ Previous studies demonstrated that inhibition of autophagy in vitro with 3-methylademine leads to increased triglycerides and lipid droplet accumulation in hepatocytes ${ }^{6}$ and that the defective hepatic autophagy-related gene $7(\operatorname{Atg} 7)$ in conjunction with obesity causes insulin resistance. ${ }^{7}$ On the other hand, adipose-specific Atg7-deleted mice exhibit lower body weight, decreased white adipose tissues, and increased insulin sensitivity, all of which contribute to diet-induced obesity. ${ }^{6,8}$ In addition, skeletal muscle-specific Atg7-deleted mice have "lean" phenotypes supported by decreased fat mass and amelioration of insulin resistance, ${ }^{9}$ indicating that autophagy is a key mechanism for regulation of host lipid metabolism. However, we still do not know whether controlling the autophagy pathway could be an environmental factor for regulation of energy balance.

\footnotetext{
${ }^{1}$ Mucosal Immunology Laboratory, Department of Convergence Medicine, University of Ulsan College of Medicine/Asan Medical Center, Seoul, Korea. ${ }^{2}$ Department of

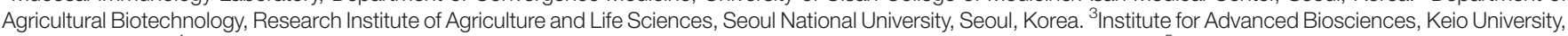
Yamagata, Japan. ${ }^{4}$ Department of Biochemistry, Graduate School of Pharmacological Science, Keio University, Tokyo, Japan. ${ }^{5}$ Department of Molecular and Life Science, College of Science and Technology, Hanyang University, Ansan, Korea. ${ }^{6}$ Division of Endocrinology and Metabolism, Department of Internal Medicine, University of Ulsan College of Medicine/Asan Medical Center, Seoul, Korea. ${ }^{7}$ Department of Internal Medicine, Yonsei University, Wonju College of Medicine, Wonju, Korea. ${ }^{8}$ Laboratory of Pharmaceutics, College of Pharmacy, Kangwon National University, Chuncheon, Korea and ${ }^{9}$ Laboratory of Microbiology and Immunology, College of Pharmacy, Kangwon National University, Chuncheon, Korea. Correspondence: M-N Kweon (mnkweon@amc.seoul.kr)
} 
Obesity is associated with substantial changes in the composition and metabolic function of the gut microbiota, which may have therapeutic potential. ${ }^{10}$ In initial studies, data from mice models and human volunteers with lean and obese phenotypes showed that changes in the relative abundance of specific phyla such as Firmicutes and Bacteroidetes are associated with obesity. ${ }^{11,12}$ It has been hypothesized that variations in abundance of gut microbiota result in different yields of energy from the diet. ${ }^{12}$ Mice deficient in TLR5 develop metabolic syndromes that include insulin resistance and increased adiposity. These are closely correlated with changes in the composition of their gut microbiota. ${ }^{13}$ Moreover, alteration in gut microbiota by antibiotic treatment increases host adiposity ${ }^{14}$ and gnotobiotic mice given fecal microbiota from obese or lean volunteers representing donor's phenotypes. ${ }^{15}$ In terms of energy expenditure, commensal microbes can contribute to obesity by providing digestive enzymes, by regulating fat storage, ${ }^{16}$ and by producing short-chain fatty acids (SCFAs). ${ }^{8}$

In this study, we identified lean phenotypes in $\operatorname{Atg} 7^{\Delta \mathrm{CD} 11 \mathrm{c}}$ mice that had improved insulin resistance and lower body weight and fat mass. Remarkably, these phenotypes were dependent on expansion of a specific commensal bacterium, Bacteroides acidifaciens $(B A)$, which subsequently altered the commensal bacteria community. Of note, $B A$ administration resulted in amelioration of metabolic disorders in the mice. Our results suggest that $B A$ may be a potential agent for modulating metabolic disorders such as diabetes and obesity.

\section{RESULTS}

\section{Atg $7^{\mathrm{ICD} 11 \mathrm{c}}$ mice showed lean phenotypes with reduced} body weight and fat mass

To address the role of autophagy in the immune cells for development of metabolic disorders, we monitored body weight and behavior of Atg7 conditional knockout mice in dendritic cells $\left(\operatorname{Atg} 7^{\Delta \mathrm{CD11c}}\right)$, in gut epithelial cells $\left(\operatorname{Atg} 7^{\Delta v i l l i n}\right)$, and in macrophages $\left(\operatorname{Atg} 7^{\Lambda \mathrm{LysM}}\right)$. Mice were fed with normal chow diet (NCD). As mice aged, we unexpectedly found that the difference in body weight between $\operatorname{Atg} 7^{\Delta \mathrm{CD} 11 \mathrm{c}}$ mice and their control littermates $\left(A \operatorname{tg} 7^{\text {flox/flox }(f / f)}\right)$ gradually increased (Figure 1a). No significant changes in body weight were found in $\operatorname{Atg} 7^{\Delta \text { villin }}$ or $A \operatorname{tg} 7^{\Delta \mathrm{LysM}}$ mice (data not shown). Of note, 24-week-old $\operatorname{Atg} 7^{\Delta \mathrm{CD} 11 \mathrm{c}}$ mice had significantly lower body weight and fat mass than $A \operatorname{tg} 7^{\mathrm{f} / \mathrm{f}}$ mice (Figure 1a,b). Both male and female mice had lean phenotypes (Atg $7^{\Delta \mathrm{CD} 11 \mathrm{c}}$; Supplementary Figure $\mathbf{1}$ online). Magnetic resonance imaging analysis further revealed that the abdominal adipose tissue masses in both axial and coronal directions were significantly reduced in the $\operatorname{Atg} 7^{\Delta \mathrm{CD} 11 \mathrm{c}}$ mice when compared with the littermate $\operatorname{Atg} 7^{\mathrm{f} / \mathrm{f}}$ mice (Figure 1c). In addition, the size of a single adipocyte in visceral adipose tissues obtained from $\operatorname{Atg} 7^{\Delta \mathrm{CD} 11 \mathrm{c}}$ mice was significantly smaller than that of $\operatorname{Atg} 7^{\mathrm{f} / \mathrm{f}}$ mice (Figure 1d). We also found that high fat diet (HFD)-fed $\operatorname{Atg} 7^{\Delta \mathrm{CD} 11 \mathrm{c}}$ mice had reduced body weight when compared with the HFD-Atg $7^{\mathrm{f} / \mathrm{f}}$ mice (Supplementary Figure 2). To clarify the involvement of systemic and mucosal inflammation in the lean phenotype $A \operatorname{tg} 7^{\Delta \mathrm{CD} 11 \mathrm{c}}$ mice, we measured proinflammatory cytokine levels in serum and mRNA expression of $\mathrm{F} 4 / 80$ and $\mathrm{TNF} \alpha$ in visceral adipose tissues and did histological analyses of small and large intestines. We found similar or even decreased levels of several indicators of systemic and mucosal inflammation in the $\operatorname{Atg} 7^{\Delta \mathrm{CD} 11 \mathrm{c}}$ mice, indicating the lean phenotype chronically shown in $\operatorname{Atg} 7^{\Delta \mathrm{CD} 11 \mathrm{c}}$ mice is not associated with inflammation (Supplementary Figure 3). Of note, higher insulin and subsequent lower glucose levels were detected in the serum of $\operatorname{Atg} 7^{\Delta \mathrm{CD} 11 \mathrm{c}}$ mice than in $\operatorname{Atg} 7^{\mathrm{f} / \mathrm{f}}$ mice under non-fasting conditions (Figure 1e). Insulin resistance as determined by glucose tolerance test (GTT) and insulin tolerance test (ITT) was significantly improved in $\operatorname{Atg} 7^{\Delta \mathrm{CD} 11 \mathrm{c}}$ mice when compared with littermate $A t g 7^{\mathrm{f} / \mathrm{f}}$ mice (Figure 1f). Taken together, these data indicate that aged $\operatorname{Atg} 7^{\Delta \mathrm{CD} 11 \mathrm{c}}$ mice had lean phenotypes with reduced fat mass and improved glucose homeostasis.

\section{Low levels of SCFAs in feces of $\boldsymbol{A t g} 7^{1 \mathrm{CD} 11 \mathrm{c}}$ mice}

Because aged $A \operatorname{tg} 7^{\triangle \mathrm{CD} 11 \mathrm{c}}$ mice had decreased body weight and fat mass, we next conducted metabolome analysis by capillary electrophoresis time-of-flight mass spectrometry (CE-TOF-MS) and gas chromatography mass spectrometry in feces for correlation between lean phenotypes and energy utilization. Although principal component analysis showed a weak correlation (data not shown), individual plots of $\operatorname{Atg} 7^{\Delta \mathrm{CD} 11 \mathrm{c}}$ mice in orthogonal partial least squares discriminate analysis were clearly segregated from those of Atg $7^{\mathrm{f} / \mathrm{f}}$ mice (Supplementary Figure 4A). Moreover, some SCFAs, such as acetate, butyrate, propionate, and lactate, were located at remote spots from the axis (Supplementary Figure 4B), indicating that those factors contribute to separating $A \operatorname{tg} 7^{\mathrm{f} / \mathrm{f}}$ and $A \operatorname{tg} 7^{\Delta \mathrm{CD} 11 \mathrm{c}}$ mice. Indeed, the amounts of fecal acetate, butyrate, and propionate in $\operatorname{Atg} 7^{\Delta \mathrm{CD} 11 \mathrm{c}}$ mice were significantly decreased, whereas the lactate level in $\operatorname{Atg} 7^{\Delta \mathrm{CD} 11 \mathrm{c}}$ mice was higher than in $A \operatorname{tg} 7^{\mathrm{f} / \mathrm{f}}$ mice (Supplementary Figure 4C).

\section{Commensal bacteria are associated with the lean phenotype of aged $\operatorname{Atg} 7^{\mathrm{ACD} 11 \mathrm{c}}$ mice}

To address whether commensal bacteria are related to the lean phenotype of $A \operatorname{tg} 7^{\Delta \mathrm{CD} 11 \mathrm{c} c}$ mice, we used co-housing $(\mathrm{CH})$ and fecal microbiota transplantation (FMT) experiments. Beginning at birth, $\operatorname{Atg} 7^{\Delta \mathrm{CD} 11 \mathrm{c}}$ and $\operatorname{Atg} 7^{\mathrm{f} / \mathrm{f}}$ mice shared cages and were exposed to feces. The $\operatorname{Atg} 7^{\mathrm{f} / \mathrm{f}}$ mice that shared cages with $\operatorname{Atg} 7^{\Delta \mathrm{CD} 11 \mathrm{c}}$ mice gained less body weight and fat than the $\operatorname{Atg} 7^{\mathrm{f} / \mathrm{f}}$ mice that did not share cages (Figure 2a,b; Supplementary Figure 5). Also, the $A \operatorname{tg} 7^{\Delta \mathrm{CD} 11 \mathrm{c}}$ mice that shared cages with Atg $\mathrm{f}^{\mathrm{f} / \mathrm{f}}$ mice gained more body weight and fat than the Atg $7^{\Delta \mathrm{CD} 11 \mathrm{c}}$ mice that did not share cages (Figure 2a,b; Supplementary Figure 5). To confirm whether the phenotype of $\mathrm{CH}$ mice is mediated by commensal microorganisms, after the $\mathrm{CH}$ experiment, we moved mice to individual cages. As shown in Figure 2c, the $\operatorname{Atg} 7^{\Delta \mathrm{CD} 11 \mathrm{c}}$ mice gained less body weight when they were housed alone but the $\operatorname{Atg} 7^{\mathrm{f} / \mathrm{f}}$ mice did not. In addition, wild-type B6 mice orally given 
a

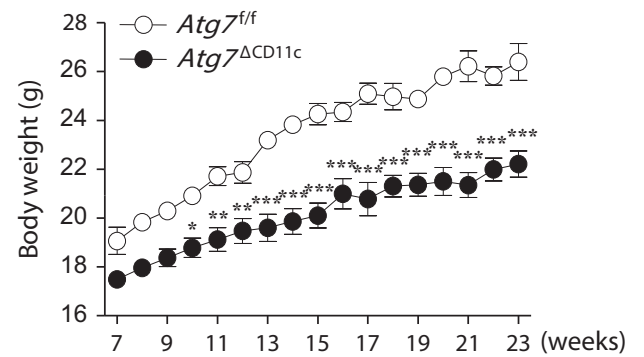

b

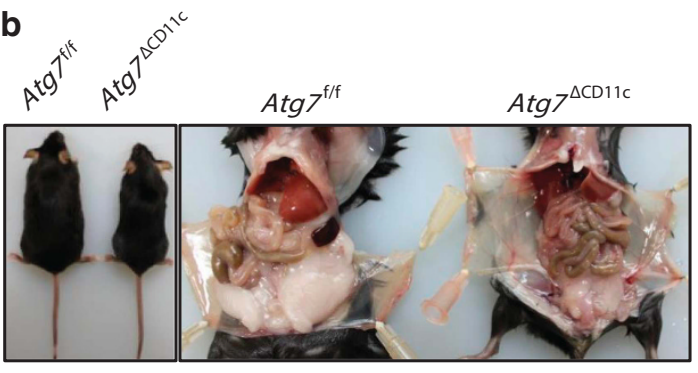

d
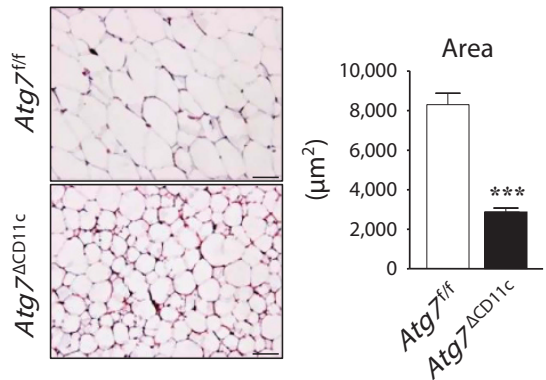
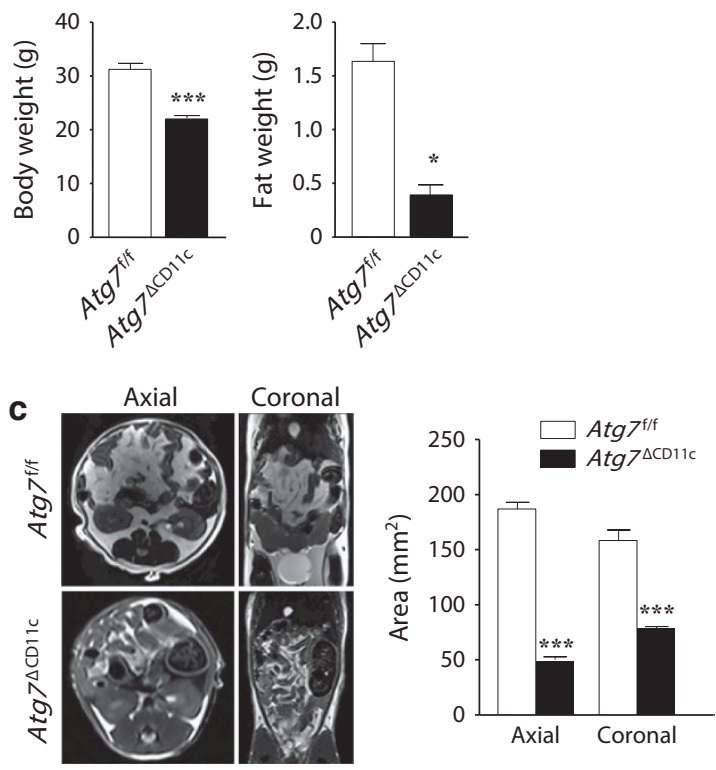

e

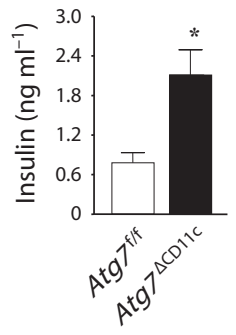

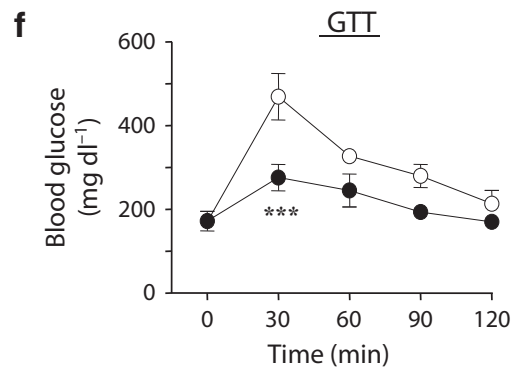

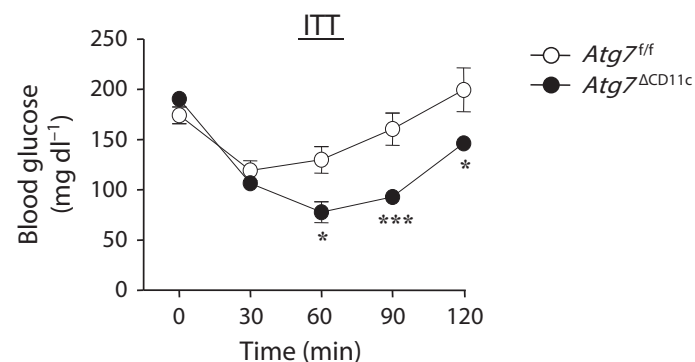

Figure 1 Lean phenotypes were discovered in $\operatorname{Atg} 7^{\Delta \mathrm{CD} 11 \mathrm{c}}$ mice. (a) Body weight changes of $\operatorname{Atg} 7^{\mathrm{f} / \mathrm{f}}$ and $\operatorname{Atg} 7^{\mathrm{ACD} 11 \mathrm{c}}$ mice monitored for 23 weeks (left panel). Body weight and fat mass of 24-week-old male $A \operatorname{tg} 7^{t / f}$ and $A \operatorname{tg} 7^{\Delta \mathrm{CD} 11 \mathrm{c}}$ mice fed with normal chow diet (NCD) (right panel) (total $n=8$ ).

(b) Representative photos of 24-week-old $A \operatorname{tg} 7^{\mathrm{t} / \mathrm{f}}$ and $A \operatorname{tg} 7^{\mathrm{CDD11C}}$ mice. (c) Magnetic resonance images of abdominal adipose tissues from 24-week-old male $A \operatorname{tg} 7^{t^{\prime /}}$ and $A \operatorname{tg} 7^{\Delta C D 11 \mathrm{c}}$ mice fed with NCD. (d) Histological changes of adipose tissues (left panel) and size of adipocytes (right panel) of $A t g 7^{/ / f}$ and $A \operatorname{tg} 7^{\triangle C D 11 \mathrm{c}}$ mice. Scale bars $=50 \mu \mathrm{m}$. (e) Levels of glucose and insulin in serum of NCD-fed Atg $7^{/ / f}$ and $A \operatorname{tg} 7^{\Delta C D 11 \mathrm{c}}$ mice under non-fasting conditions. (f) Glucose tolerance test (GTT) and insulin tolerance test (ITT) in male $A \operatorname{tg} 7^{t / f}$ and $A \operatorname{tg} 7^{\Delta \mathrm{CD} 11 \mathrm{c}}$ mice (total $\left.n=7\right)$. Data shown are the mean values $\pm \mathrm{s}$.e.m. from individual mice from 3 independent experiments with 3-4 mice per experiment. Statistical analyses were done with two-tailed paired $t$-test (a-right, d, and $\mathbf{e}$ ) and two-way ANOVA with Bonferroni post hoc test (a-left and f). ${ }^{*} P<0.05,{ }^{* *} P<0.01$, and ${ }^{* * *} P<0.001$.

fecal extract from $\operatorname{Atg} 7^{\mathrm{ACD11c}}$ mice daily for 12 weeks had significantly lower body weight and fat mass than those transferred from wild-type B6 or $\operatorname{Atg} 7^{\mathrm{f} / \mathrm{f}}$ mice (Figure 2d). Of note, wild-type B6 mice given fecal extracts from $\operatorname{Atg} 7^{\Delta \mathrm{CD} 11 \mathrm{c}}$ mice had higher insulin levels and subsequently lower serum glucose levels than those that received extracts from $\operatorname{Atg} 7^{\mathrm{f} / \mathrm{f}}$ mice (Figure 2e). Overall, these results imply that commensal bacteria have an indispensable role in the lean phenotype of $\operatorname{Atg} 7^{\mathrm{CCD} 11 \mathrm{c}}$ mice.

\section{Expansion of $B A$ in feces of $A \operatorname{tg} 7^{\perp C D 11 c}$ mice}

To see the diversity and composition of gut commensal bacteria, we next adopted metagenomic analysis. In pyrosequencing analysis, the proportion of Bacteroidetes, Firmicutes, and Proteobacteria, the primary populations of gut microbiota at the phylum level, was similar in the feces of $\operatorname{Atg} 7^{\mathrm{f} / \mathrm{f}}$ and $\operatorname{Atg} 7^{\mathrm{CDDl1c}}$ mice (Figure 3a). The proportion of Bacteroidia (class), Bacteroidales (order), Bacteroidaceae (family), and Bacteroides (genus) was also similar or not significantly 
a

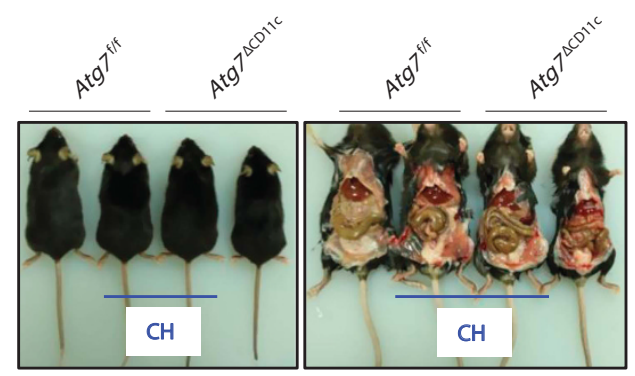

b

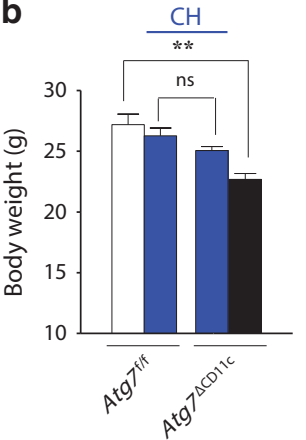

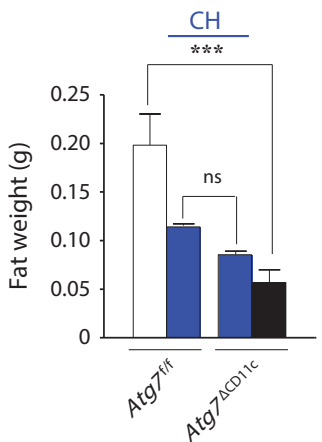

C

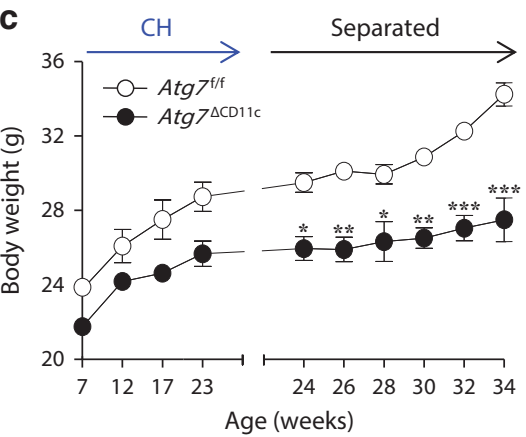

d
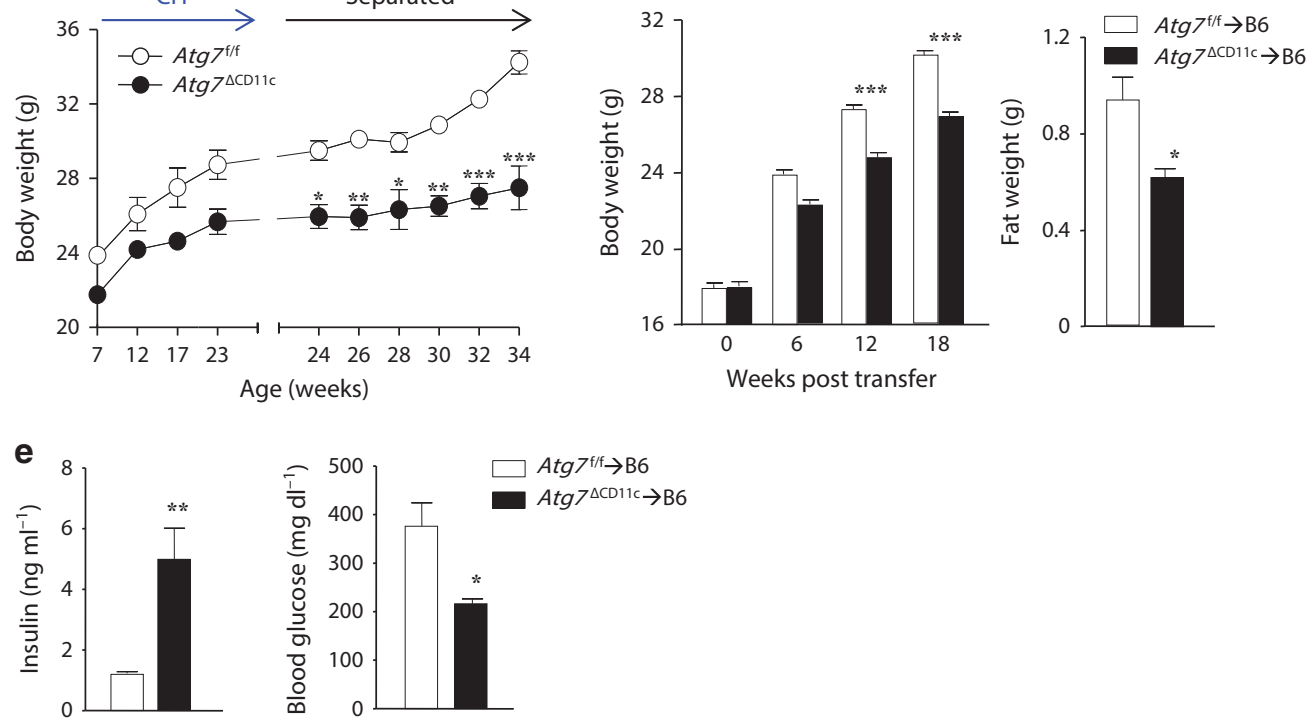

Figure 2 Lean phenotypes originate in gut commensal bacteria. (a) Representative photos of 24-week-old male $\operatorname{Atg} 7^{4 / \mathrm{f}}$ and $\operatorname{Atg} 7^{\mathrm{ACD} 11 \mathrm{c}}$ mice after co-housing (CH; center) or separated (far left and far right). (b) Body weight and fat mass of 24-week-old $\operatorname{Atg}^{7^{/ f}}$ and $A \operatorname{tg} 7^{\Delta \mathrm{CD} 11 \mathrm{c}}$ mice in CH or separate cages (total $n=4$ ). (c) After $\mathrm{CH}$, body weight of each mouse was monitored for another 10 weeks (total $n=9$ ). (d) Body weight and fat mass of naive B6 recipient mice monitored daily for 18 weeks after fecal transfer of $A \operatorname{tg} 7^{/ / f}$ or $A \operatorname{tg} 7^{\Delta \mathrm{CD} 11 \mathrm{c}}$ mice (total $\left.n=5\right)$. (e) Insulin and glucose levels in serum of B6 recipient mice after transfer of fecal extract of $A \operatorname{tg} 7^{t / f}$ or $A \operatorname{Ag} 7^{\Delta \mathrm{CD} 11 \mathrm{c}}$ mice under non-fasting conditions (total $n=5$ ). Data shown are the mean values \pm s.e.m. from individual mice from 2 independent experiments with 2-5 mice per experiment. Statistical analyses were performed with two-tailed paired $t$-test $(\mathbf{b}, \mathbf{e})$ and two-way ANOVA with Bonferroni post hoc test $(\mathbf{c}, \mathbf{d}) .{ }^{\star} P<0.05,{ }^{* \star} P<0.01,{ }^{* \star *} P<0.001$; ns, not significant.

changed (Figure 3b). However, when we analyzed species levels, the ratio of $B A$ was significantly greater in the feces of $\operatorname{Atg} 7^{\Delta \mathrm{CD} 11 \mathrm{c}}$ mice than in $\operatorname{Atg} 7^{\mathrm{f} / \mathrm{f}}$ mice $(5.48 \pm 1.76 \%$ vs. $0.77 \pm 0.18 \%$ ) (Figure 3c, red arrow; Supplementary Figures 6 and 7). On the other hand, the proportion of other Bacteroides species, including $B$. sartorii, in the commensal bacteria was not altered in the feces of $\operatorname{Atg} 7^{\Delta \mathrm{CD} 11 \mathrm{c}}$ or $\operatorname{Atg} 7^{\mathrm{f} / \mathrm{f}}$ mice (Supplementary Figure 7 ). In alpha diversity, while the species richness (Chao 1 index) of fecal microbiota of $\operatorname{Atg} 7^{\Delta \mathrm{CD} 11 \mathrm{c}}$ mice was significantly decreased, the community diversity (Shannon/Simpson index) was similar to those of $A \operatorname{tg} 7^{\mathrm{f} / \mathrm{f}}$ mice (Supplementary Table). To further confirm the expansion of $B A$ in $A \operatorname{tg} 7^{\Delta \mathrm{CD} 11 \mathrm{c}}$ mice with lean phenotype, we used fluorescence in situ hybridization analysis. As shown in Figure 3d, increased numbers of $B A$ were detected in the lumen of the colon and few $B A$ were internalized in the colonic epithelial cells of $A \operatorname{tg} 7^{\Delta \mathrm{CD} 11 \mathrm{c}}$ mice. We also found expansion of BA in the feces of $A \operatorname{tg} 7^{\mathrm{f} / \mathrm{f}}$ mice co-housed with $\operatorname{Atg} 7^{\Delta \mathrm{CD} 11 \mathrm{c}}$ mice (Supplementary Figure 8). Taken together, these findings show that among commensal bacteria, $B A$ is magnified in the gut of $A \operatorname{tg} 7^{\Delta C D 11 c}$ mice with lean phenotype.

\section{Oral administration of $B A$ leads to lean phenotypes in HFD- fed B6 mice}

To clarify whether expanded $B A$ can regulate lipid metabolisms, we obtained $B A$ (JCM10556), cultured the organisms to obtain a large volume, and fed them to naive B6 mice. To determine optimal conditions for administration, we quantified $B A$ in colon tissue and feces of mice fed with $B A\left(5 \times 10^{9} \mathrm{CFU}\right.$ per $100 \mu \mathrm{l})$ by fluorescence in situ hybridization analysis. Numerous $B A$ were detected in the lumen of colon epithelium cells 1 day following oral administration (Supplementary Figure 9A). The number of $B A$ recovered from feces peaked 2 
a

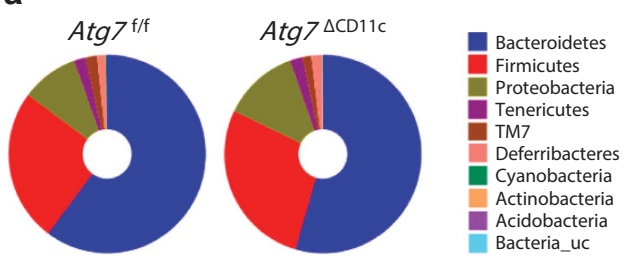

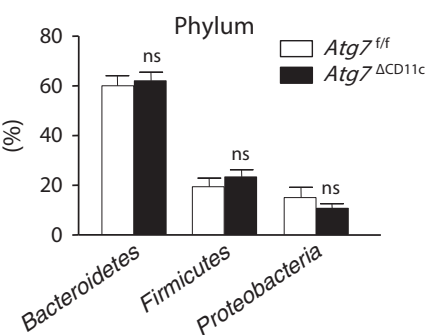

b
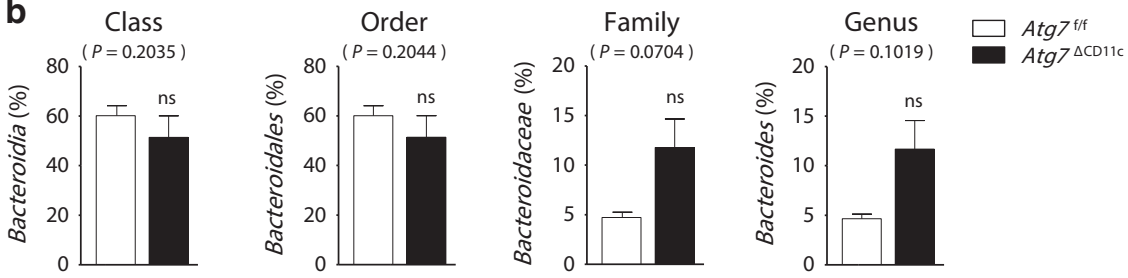

C
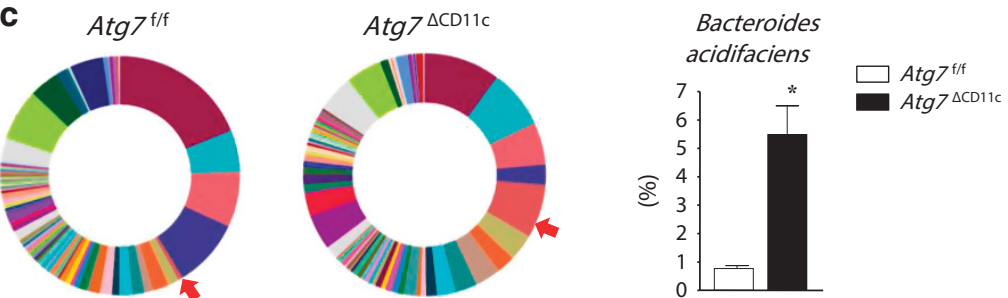

d
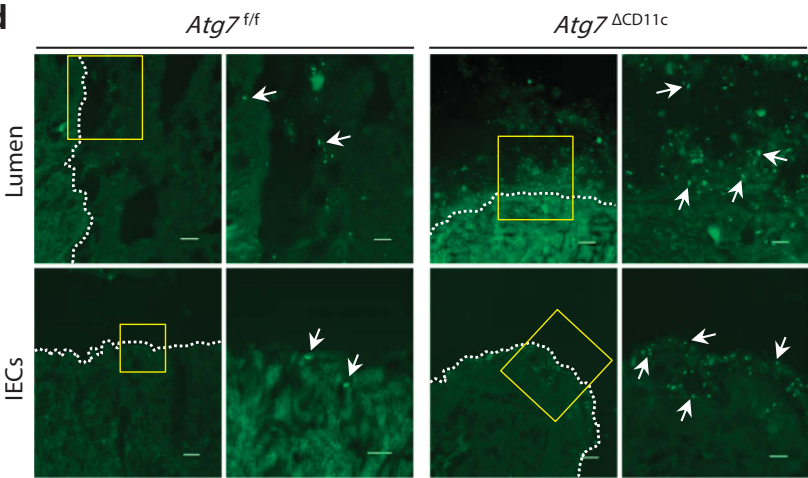

Figure 3 B. acidifaciens (BA) among gut commensal bacteria was expanded in the feces of $A \operatorname{tg} 7^{\Delta \mathrm{CD} 11 \mathrm{c}}$ mice. Pyrosequencing data analyzed in terms of phylum (a) and from class to genus (b) levels (total $n=6$ ). (c) Representative pie charts for species levels show proportion of BA in feces detected by pyrosequencing analysis. Red arrows = BA. (d) Increased numbers of BA in the intestinal epithelial cells (IECs) and lumen of colon of Atg $7^{/ / 4}$ and $\operatorname{Atg} 7^{\Delta \mathrm{CD} 11 \mathrm{c}}$ mice determined by fluorescence in situ hybridization probe specific for BA (total $n=5$ ). Scale bar $=100 \mu \mathrm{m}$. White arrow indicates representative BA. Data shown are the mean values \pm s.e.m. from individual mice from 2 independent experiments with $2-3$ mice per experiment. Statistical analyses were done with two-tailed paired $t$-test. ${ }^{*} P<0.05$; ns, not significant.

days after oral feeding and then rapidly disappeared (Supplementary Figure 9B). Oral administration of $B A$ reduced body weight and fat mass in wild-type B6 mice fed with NCD or HFD without affecting food intake (Figures 4a-c; Supplementary Figure 10A-C). In contrast, B. sartorii-fed mice used as controls did not lose body weight (Supplementary Figure 11). In addition, the size of a single adipocyte in epididymal adipose tissue of $B A$ - and HFD-fed B6 mice was significantly smaller than that of PBS- and HFD-fed mice (Figure 4d). In addition, insulin resistance as determined by GTT and ITT was significantly improved in BA- and HFD-fed mice as compared with PBS- and HFD-fed mice (Figure 4e).
To further assess the effects on hepatic and peripheral insulin sensitivity by feeding with $B A$, we employed a hyperinsulinemic-euglycemic clamp technique with heat-inactivated $B A$ as a control. Interestingly, $B A$ feeding improved both hepatic and peripheral insulin sensitivity, while heat-inactivated $B A$ showed similar, but not statistically significant, effects (Supplementary Figure 12). Oral administration of $B A$ reduced butyrate in the feces of NCD-fed mice, but no significance differences were found in the levels of acetate, propionate, and lactate (Supplementary Figure 13A). Similar tendencies were observed in the HFD-fed groups (Supplementary Figure 13B). To further assess 


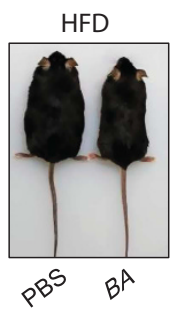

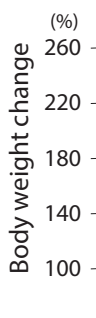

$-\mathrm{PBS}$
$-B A$

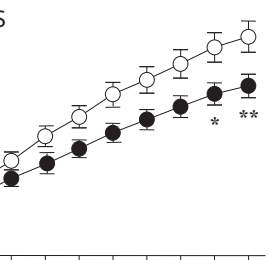

$\begin{array}{lllllllllll}0 & 1 & 2 & 3 & 4 & 5 & 6 & 7 & 8 & 9 & 10 \\ \text { (Weeks) }\end{array}$

b

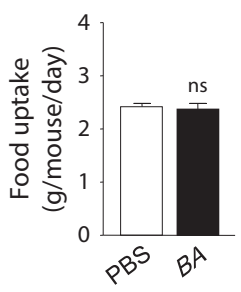

C
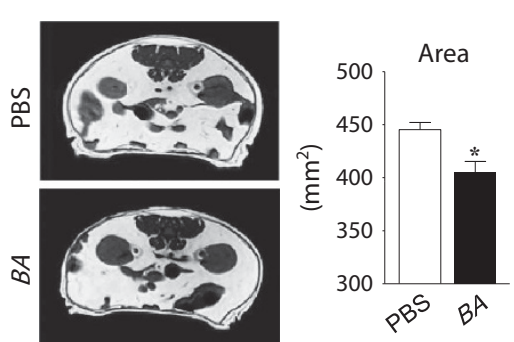

d
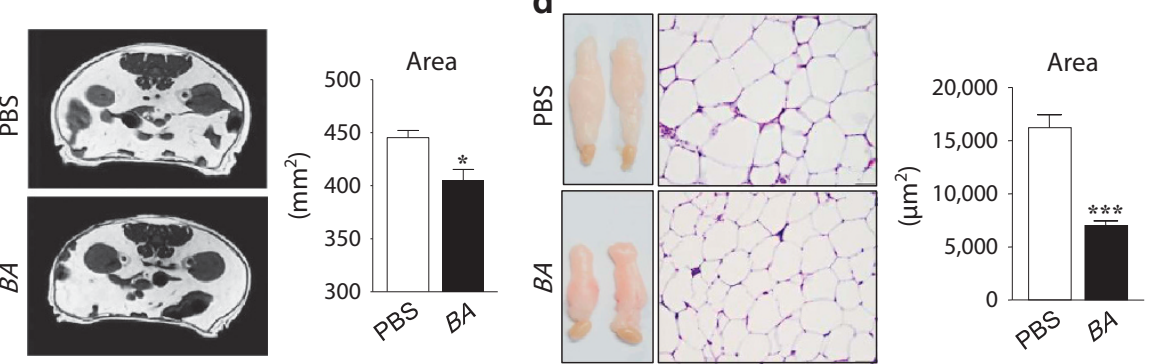

e
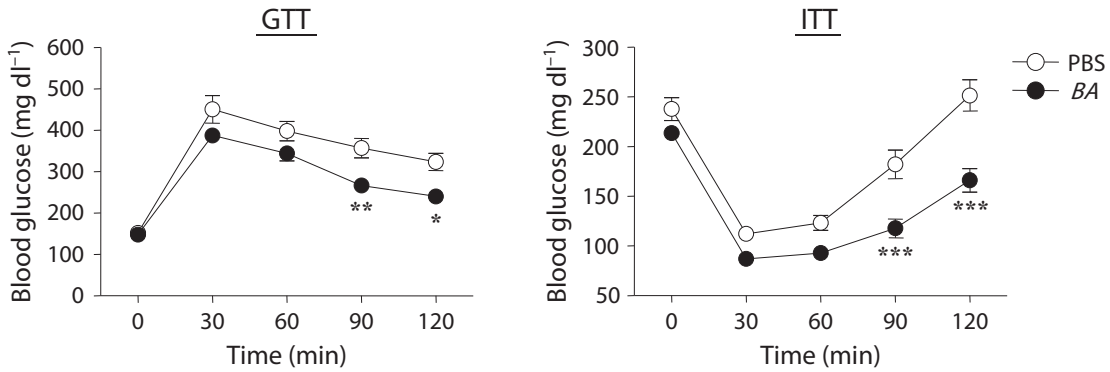

f
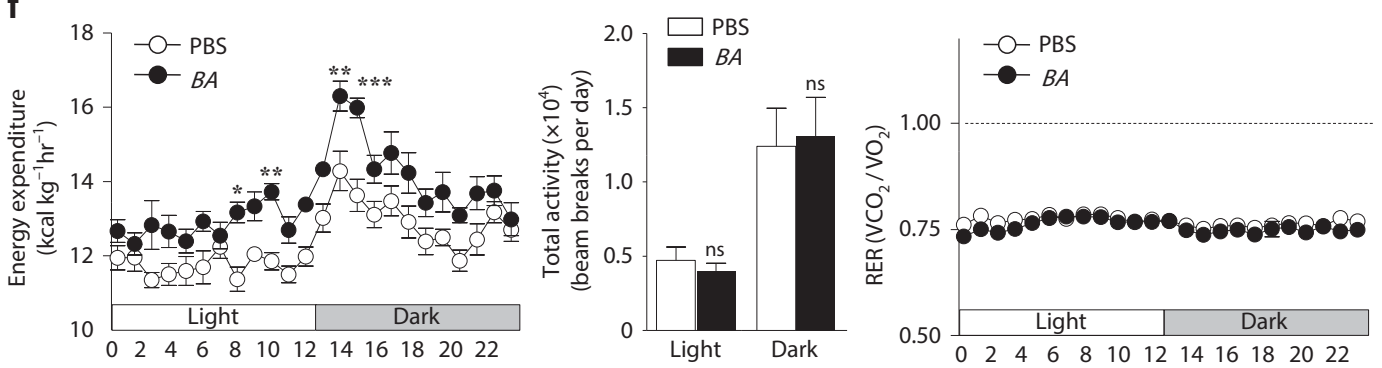

Figure 4 B. acidifaciens (BA) regulates body weight and fat mass in diet-induced mouse obesity in B6 mice. (a) Representative photos of PBS- and BAfed mice with high-fat diet (HFD; left panel). Group body weights were monitored for 10 weeks (right panel). BA was administered orally $\left(5 \times 10^{9} \mathrm{CFU}\right.$ per $100 \mu$ l) daily (total $n=10$ ). (b) Oral food intake with PBS or BA (total $n=10$ ). (c) Magnetic resonance imaging of PBS- and BA-fed mice. (d) Histological changes of adipose tissues (left panel) and size of adipocytes (right panel) of PBS- and BA-fed mice during HFD (total $n=9$ ). (e) Glucose tolerance test (GTT; left panel, total $n=9$ ) and insulin tolerance test (ITT; right panel, total $n=12$ ) results using serum of PBS- and BA-fed mice at indicated time points after intraperitoneal injection of glucose or insulin. (f) Energy expenditure, total activity, and respiratory exchange ratio (RER) of PBS- or BA-fed mice (total $n=10$ ). Data shown are the mean values \pm s.e.m. from individual mice from 3 independent experiments with $3-5$ mice per experiment. Statistical analyses were done with two-tailed paired $t$-test (b-d) and with two-way ANOVA with Bonferroni post hoc test $(\mathbf{a}, \mathbf{e}, \mathbf{f}) .{ }^{*} P<0.05,{ }^{\star \star} P<0.01,{ }^{* \star \star} P<0.001$; ns, not significant.

energy expenditure, activity, and substrate utilization, we next monitored mice fed with $B A$ after being housed individually in comprehensive laboratory animal monitoring system cages for 5 days. Although groups of mice fed with PBS or BA exhibited a similar locomotor activity and respiratory exchange ratio, $B A-$ and HFD-fed mice expanded more energy than PBS- and HFDfed mice (Figure 4f). NCD-fed mice given oral $B A$ showed similar effects, except for energy expenditure (Supplementary Figure 10). Collectively, long-term administration of $B A$ promoted energy expenditure and consequently caused dominant lean phenotypes in diet-induced obese mice.

\section{Mice with lean phenotypes exhibit enhanced peroxisome proliferator-activated receptor $\alpha$ expression in adipose tissues}

Because decreased body weight and fat mass were detected in $\operatorname{Atg} 7^{\Delta \mathrm{CD} 11 \mathrm{c}}$, FMT B6, and BA-fed B6 mice, we further analyzed gene expression levels as related to lipid metabolism in adipose 

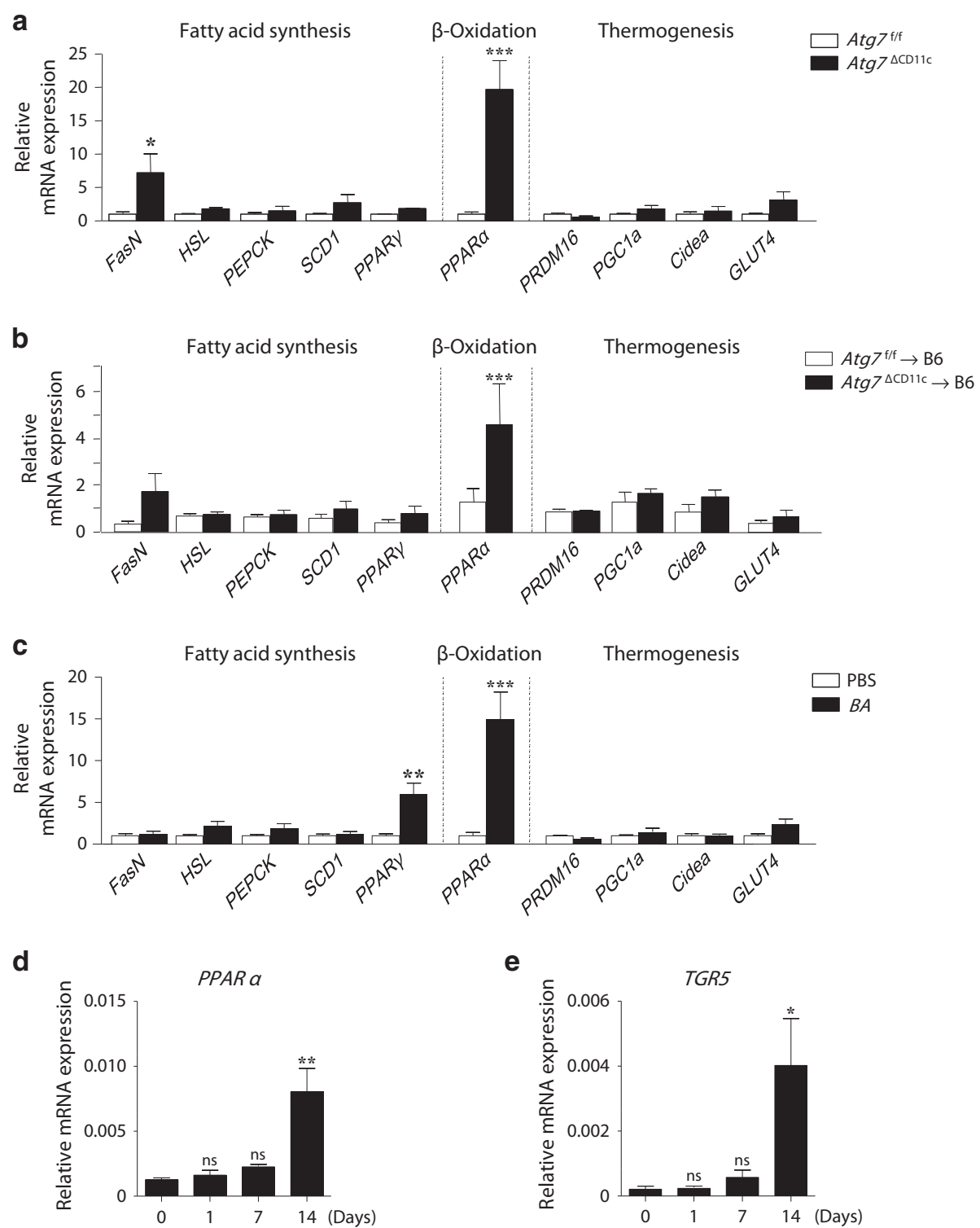

Figure 5 B. acidifaciens (BA) promotes fat oxidation in adipose tissues through peroxisome proliferator-activated receptor $\alpha$ (PPAR $\alpha$ ) activation. Expression level of mRNA genes as related to fatty acid synthesis (FasN, HSL, PEPCK, SCD1, and PPAR $\gamma$ ), $\beta$-oxidation (PPAR $\alpha$ ), and thermogenesis (PRDM16, PGC1a, Cidea, and GLUT4) was determined by real-time PCR using epididymal adipose tissues of $\operatorname{Atg} 7^{1 / \mathrm{f}}$ and $A \operatorname{tg} 7^{\Delta \mathrm{CD} 11 \mathrm{c}}$ mice (a; total $\left.n=8\right)$, fecal microbiota transplanted mice (b; total $n=8)$, and BA-fed mice (c; total $n=8)$ at the end point of each experiment. Expression levels of PPAR $\alpha(\mathbf{d})$ and TGR5 (e) in adipose tissue were analyzed by RT-PCR 1,7 , and 14 days after daily BA administration. Data shown are the mean values \pm s.e.m. from individual mice from 2 independent experiments with 3-5 mice per experiment. Statistical analyses were done with two-way ANOVA with Bonferroni post hoc test (a-c) and with Mann-Whitney $t$-test (d, e). ${ }^{\star} P<0.05,{ }^{\star \star} P<0.01,{ }^{* \star \star} P<0.001$; ns, not significant.

tissue, liver, and the small intestine. Of note, gene expression related to lipid $\beta$-oxidation, especially peroxisome proliferatoractivated receptor alpha $(P P A R \alpha)$, was significantly enhanced only in the epididymal adipose tissues of $A \operatorname{tg} 7^{\Delta \mathrm{CD} 11 \mathrm{c}}$ mice (Figure 5a). We found no significant changes in this gene in the small intestine and liver (Supplementary Figure 14A and B). Consistent with these results, expression of $P P A R \alpha$ was significantly upregulated in epididymal adipose tissues of B6 mice given fecal extracts of $A \operatorname{tg} 7^{\Delta \mathrm{CD} 11 \mathrm{c}}$ mice or fed with HFD and $B A$ for 10 weeks (Figure $\mathbf{5 b}, \mathbf{c}$ ). To clarify whether enhanced $\beta$-oxidation levels are directly activated by bacteria alone and are not the product of lean phenotypes, we next tested
$P P A R \alpha$ expression levels in B6 mice following $B A$ administration in a time-dependent manner. Of interest, mRNA levels of PPAR $\alpha$ in epididymal adipose tissues of B6 mice were significantly enhanced 2 weeks after $B A$ administration (Figure 5d). We also assessed the expression levels of TGR5, a G-protein-coupled bile acid receptor that can stimulate energy expenditure through PPAR $\alpha$ activation. ${ }^{17,18}$ We found elevated TGR5 expression levels in adipose tissues following $B A$ administration (Figure 5e). These results suggest that lean phenotypes mediated by $B A$ might begin with lipid oxidation in adipose tissue through TGR5-PPAR $\alpha$ activation. 
a
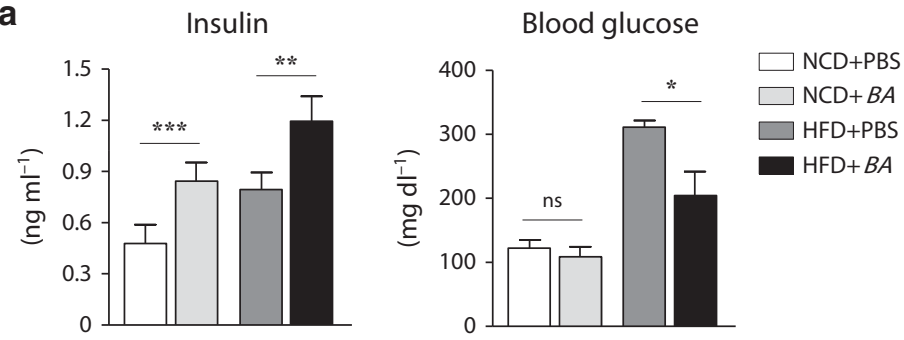

b

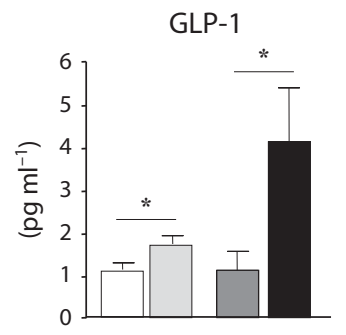

d

Cholate

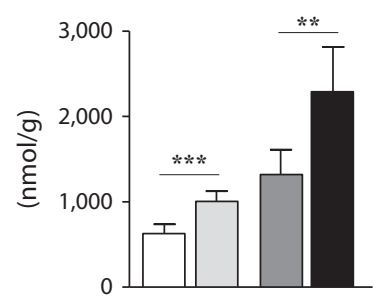

Taurine

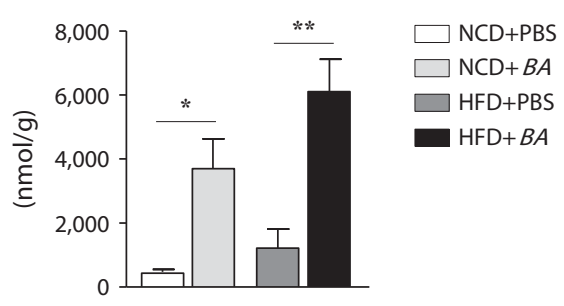

C

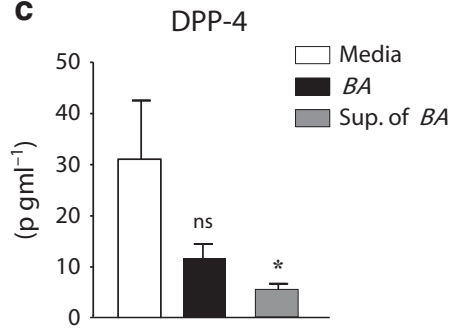

Figure 6 B. acidifaciens (BA) can regulate intestinal dipeptidal peptidase-4 (DPP-4) secretion and subsequently induce glucagon-like peptide 1 (GLP-1) production in B6 mice. Glucose and insulin levels (a) and of active GLP-1 (b) in serum of PBS- and BA-fed mice (normal chow diet, NCD; high-fat diet, HFD; total $n=8$ ). (c) At $1 \mathrm{~h}$ after administration with BA or culture supernatant of BA or medium alone into naive B6 mice, DPP-4 levels in the small intestine were detected by luminescent assay. (d) Quantification of cholate and taurine in feces of PBS- and BA-fed mice (total $n=8$ ) by capillary electrophoresis-mass spectrometry. Data shown are the mean values \pm s.e.m. from individual mice from 2 independent experiments with 3-5 mice per experiment. Statistical analyses were done with two-tailed paired $t$-test. ${ }^{*} P<0.05,{ }^{* \star} P<0.01,{ }^{* \star *} P<0.001$; ns, not significant.

\section{BA modulates glucagon-like peptide-1 production by regulating dipeptidyl peptidase- 4 and by producing bile acids}

We further addressed the role of $B A$ in the regulation of glucose homeostasis. As expected, $B A$-fed B6 mice showed higher insulin and lower glucose levels in serum than PBS-fed B6 mice, although glucose levels were not significant in BA- and NCDfed B6 mice (Figure 6a). To investigate the possibility that these increased plasma insulin levels might also be a sign of $\beta$-cell overstimulation, we stained $\alpha$ - and $\beta$-cells in the pancreas tissues 10 weeks after $B A$ feeding. We found that $B A$ feeding did not elicit $\beta$-cell overstimulation that might lead to premature $\beta$-cell failure (Supplementary Figure 15). To investigate the underlying mechanism of high levels of insulin secretion in $B A$ fed lean mice, we next studied the glucagon-like peptide-1 (GLP-1) levels that could stimulate insulin release to blood. ${ }^{19}$ The GLP-1 levels in serum were dramatically enhanced following administration of $B A$ in NCD- and HFD-fed mice (Figure 6b). Of note, the levels of dipeptidyl peptidase-4 (DPP4 ), a well-known enzyme that causes degradation of GLP- $1,{ }^{20}$ were decreased in the small intestine ileum after oral administration of $B A$ or culture supernatants (Figure $6 \mathrm{c}$ ).
In addition, we measured DPP-4 activity that reflects protein quantity (data not shown). Previous studies suggested that bile acids have a pivotal role in glucose homeostasis by stimulating GLP-1 secretion through TGR5 activation. ${ }^{21,22}$ We found significantly increased levels of cholate, salts of cholic acid (CA), and taurine deconjugated from primary bile acid in feces of B6 mice fed with $B A$ for 10 weeks but no significant loss of cholesterol (Figure 6d; Supplementary Figure 16). In addition, we obtained significantly higher levels of bile acids (i.e., cholate and taurine as shown in red box) in $\operatorname{Atg} 7^{\Delta \mathrm{CD} 11 \mathrm{c}}$ mice among the 292 metabolites analyzed by CE-TOF-MS (Supplementary Figure 17). These results indicate that $B A$ or its metabolites may reduce DPP-4 enzyme activity and subsequently result in GLP-1 activation, improving insulin sensitivity and glucose tolerance.

\section{DISCUSSION}

In this study, we found that specific gut commensal bacteria (i.e., $B A)$ was expanded in $A \operatorname{tg} 7^{\Delta \mathrm{CD} 11 \mathrm{c}}$ mice with lean phenotypes. Administration of $B A$ resulted in activation of fat oxidation through the bile acid-TGR5-PPAR $\alpha$ axis in 


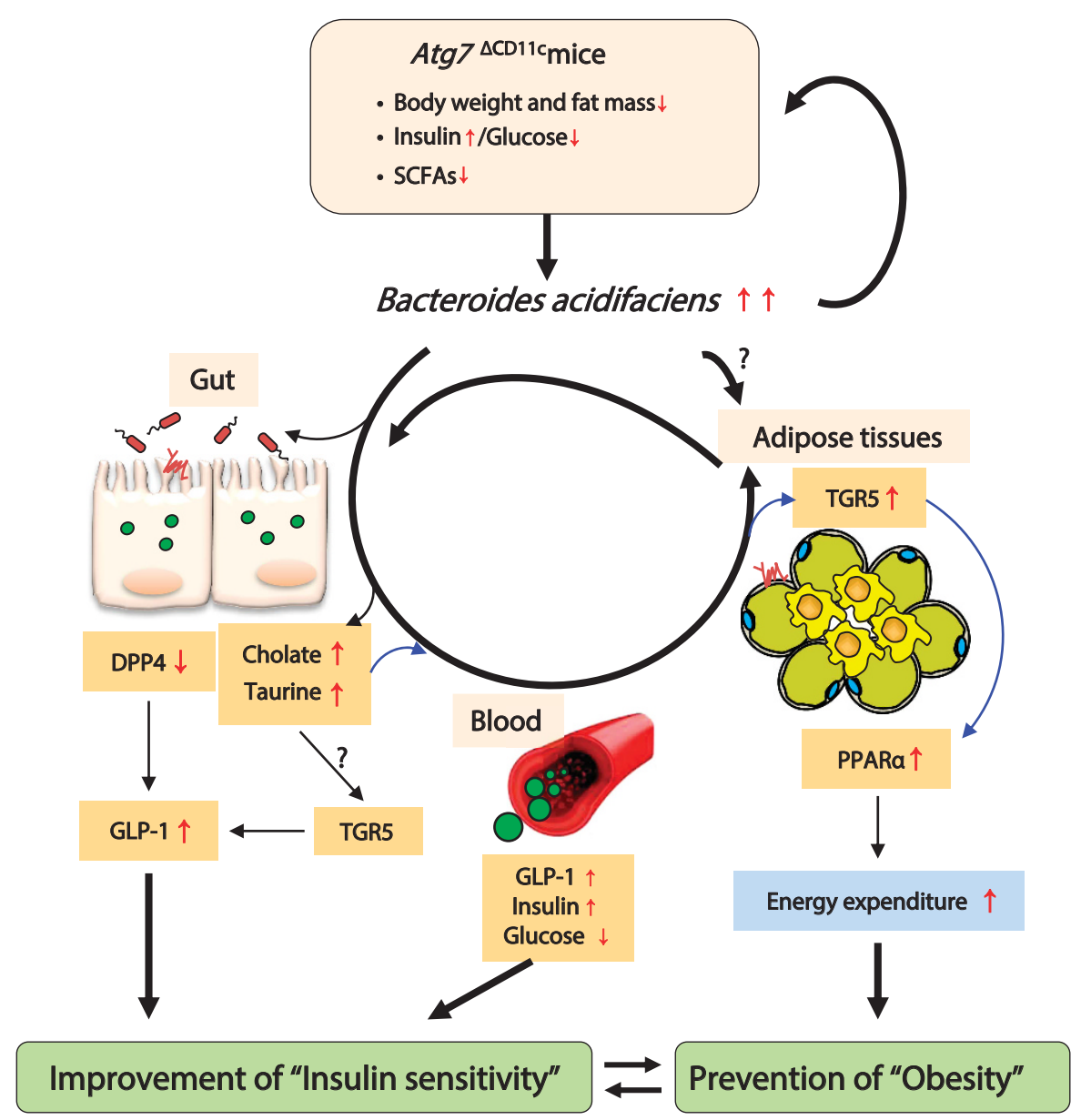

Figure 7 Proposed models of "lean bug" B. acidifaciens (BA) to protect host against insulin sensitivity and obesity. One gut commensal bacteria (i.e., BA) was expanded in Atg $7^{\mathrm{ACD11C}}$ mice with lean phenotypes. BA feeding resulted in activation of fat oxidation through the bile acid-TGR5-PPAR $\alpha$ axis in adipose tissues, which may lead to high energy expenditure. At the same time, BA activates dipeptidyl peptidase-4 (DPP-4) in the gut and subsequently increases glucagon-like peptide-1 (GLP-1), which may contribute to glucose homeostasis. Bile acids (i.e., cholate and taurine) may also contribute to GLP-1 activation through TGR5 and result in improved insulin sensitivity. PPAR $\alpha$, peroxisome proliferator-activated receptor $\alpha$; SCFAs, short-chain fatty acids.

adipose tissues, which may lead to high energy expenditure. At the same time, BA activates DPP-4 in the gut and subsequently increase GLP-1, which may contribute to glucose homeostasis. Bile acids, cholate, and taurine may also contribute to GLP-1 activation through the TGR5 receptor and result in improved insulin sensitivity. Overall, $B A$ may have a role in prevention of metabolic diseases such as diabetes and obesity (Figure 7).

$B A$ have been isolated from mouse ceca ${ }^{23}$ and human feces. ${ }^{24}$ These novel commensal bacteria are characterized as anaerobic and Gram negative. They increase IL- 6 and IL-10 production by enhancing expression of MHC class II molecules and also costimulate molecules (i.e., CD80 and CD86) on antigenpresenting cells. ${ }^{25} \mathrm{BA}$ is one of the predominant commensal bacteria that promote IgA antibody production in the large intestine. Specifically, it induces activation-induced cytidine deaminase expression. ${ }^{26,27}$ In this study, we discovered that $B A$ can also modulate insulin resistance and energy metabolism and thus that it may be of therapeutic value for treating metabolic diseases such as diabetes and obesity.
An investigation of the epidemiologic relationship between obesity and its causes found that environmental factors and host genetic background can influence the composition of gut commensal bacteria. ${ }^{28}$ The majority of gut commensal microbiota in mammals are Bacteroidetes and Firmicutes. Human and animal studies suggest that a higher ratio of Firmicutes to Bacteroidetes enables greater efficiency of gut microbiota in extracting energy from the diet, which can be one cause of adiposity. ${ }^{11,14,29}$ Others suggest that such alteration at the phylum level is insufficient to explain the mechanisms associated with adiposity and obesity. ${ }^{30,31}$ Those observations support our current findings. We found no changes in the proportion of Firmicutes and Bacteroidetes in feces of Atg $7^{\Delta \mathrm{CD} 11 \mathrm{c}}$ mice, which are prone to lean phenotypes unlike their littermate $A \operatorname{tg} 7^{\mathrm{f} / \mathrm{f}}$ mice (Figure 3a). Instead, we found that specific species (i.e., $B A$ ) among the Bacteroidetes phylum were largely expanded in the lean $\operatorname{Atg} 7^{\Delta \mathrm{CD} 11 \mathrm{c}}$ mice (Figure 3c). A recent study revealed that obese mice co-housed with mice containing a lean twin's microbiota did not have body weight increases and obesity-associated metabolic phenotypes that 
were correlated with Bacteroides such as B. cellulosilyticus, $B$. uniformis, $B$. vulgatus, $B$. thetaiotaomicron, and B. caccae. ${ }^{15}$ Furthermore, oral administration of B. uniformis CECT 7771 strain reduced metabolic disorders and immunological dysfunction in HFD-induced obese mice. ${ }^{32}$ In the present study, we first identified $B A$, which are associated with gut microbiota homeostasis, for energy harvest.

We believe that $B A$ may be tightly regulated by the autophagy mechanism of $\mathrm{CD} 11 \mathrm{c}^{+}$cells at the steady-state condition. Indeed, we found higher numbers of $B A$ in the $A t g 7$-deficient $\mathrm{CD} 11 \mathrm{c}^{+}$mice than in the Atg7-sufficient mice when cells were co-cultured in vitro with BA for $24 \mathrm{~h}$ (Supplementary Figure 18). In support of these results, previous studies showed that the autophagy-dependent pathway is crucial for intracellular bacteria digestion as observed in Atg16L1deficient dendritic cells. ${ }^{33,34}$

The gastrointestinal tract is a locus of incretin hormone products such as GLP-1 that stimulate insulin release and decrease blood glucose levels. ${ }^{19}$ GLP-1 is inactivated by the enzyme DPP-4 and thus DPP-4 inhibitor is a class of oral hypoglycemic. ${ }^{20}$ We found similar patterns of low glucose and high insulin levels in the serum of $A \operatorname{tg} 7^{\Delta \mathrm{CD} 11 \mathrm{c}}$ mice with high numbers of $B A$, in FMT mice, and in $B A$-fed mice (Figures le, $2 e$, and $\mathbf{6 a}$ ). Of note, there were significantly decreased levels of DPP-4 in the gut with increased levels of GLP-1 in the serum of $B A$-fed mice (Figure $\mathbf{6 b}, \mathbf{c}$ ). It seems likely that unknown metabolites synthesized by $B A$ or by other bacteria may directly interact with gut epithelial cells and inhibit DPP-4 activation, thereby increasing circulating GLP-1.

Two general cascades are associated with lower weight gain, reduced energy utilization/storage efficiency, and increased energy expenditure. The metabolome analysis by CE-TOF-MS and gas chromatography mass spectrometry revealed clear segregation between $\operatorname{Atg} 7^{\Delta \mathrm{CD} 11 \mathrm{c}}$ and $\operatorname{Atg} 7^{\mathrm{f} / \mathrm{f}}$ mice (Supplementary Figure 4A). Loading plots showed SCFAs such as butyric, propionic, and acetic acids were significantly lower and conversely that lactic acid was higher in $\operatorname{Atg} 7^{\Delta \mathrm{CD} 11 \mathrm{c}}$ mice than in $A \operatorname{tg} 7^{\mathrm{f} / \mathrm{f}}$ control mice (Supplementary Figure 4C). This SCFA profile is similar to that of specific pathogen-free mice fed a low-fiber diet. ${ }^{35}$ As reported, caloric extraction from diet fiber is upregulated in obese animals and humans compared with healthy controls. ${ }^{36}$ Young mice administered subtherapeutic doses of antibiotics had increased adiposity and substantially increased SCFAs in cecal contents. ${ }^{14}$ Thus, we assume that the altered microbiota of $\operatorname{Atg} 7^{\Delta \mathrm{CD} 11 \mathrm{c}}$ mice (i.e., lower richness (Supplementary Table) and expansion of $B A$ ) is related to poor caloric extraction in contrast to that of control $\operatorname{Atg} 7^{\mathrm{f} / \mathrm{f}}$ mice. Given that SCFAs are good energy sources for the host, decreased SCFA levels may reduce energy supply and result in lean phenotypes.

PPAR $\alpha$ is a nuclear receptor that contributes to regulate lipid metabolism. ${ }^{37}$ Earlier studies demonstrated that PPAR $\alpha$ activation through its agonists resulted in reduced body weight by regulating satiety and by ameliorating obesity-derived inflammation in adipose tissue. ${ }^{38,39}$ Although PPAR $\alpha^{-1-}$ mice fed with HFD showed several obesity phenotypes in terms of body weight, fat mass, and fat droplets, ${ }^{40}$ the major mechanisms by which PPAR $\alpha$ regulates lipid metabolism are regulation of fatty acid cellular uptake and stimulation of fatty acid oxidation. ${ }^{41}$ In our studies, enhanced mRNA expression levels of $P P A R \alpha$ were consistently detected only in adipose tissues from $\operatorname{Atg} 7^{\Delta \mathrm{CD} 11 \mathrm{c}}$ mice, FMT mice, and $B A$-fed mice (Figure 5), indicating that $\beta$-oxidation through PPAR $\alpha$ signaling may be a mechanism for protection against obesity provoked by specific commensal bacteria such as $B A$.

In mice, CA, a primary bile acid, is secreted as a taurineconjugated form from the gallbladder into the duodenum and then is deconjugated in the ileum by commensal bacteria. ${ }^{42}$ Recent studies have shown that the bile acid profiles in the small intestine, feces, and serum of conventionally raised mice are totally different from those of germ-free mice, suggesting that commensal bacteria can modulate gene expression levels related to bile acid synthesis, conjugation, and reabsorption. ${ }^{43}$ In the present study, significantly elevated levels of cholate and taurine were determined in feces (Figure 6d) and their receptor TGR5 in adipose tissues (Figure 5e) of B6 mice fed with $B A$. Others have shown that when the TGR5 agonists CA and taurine are administered, there is a significant improvement of body weight and fat mass in HFD-fed mice. ${ }^{22,44}$ Those authors suggest that the bile acid-TGR5-cAMP signaling pathways increase energy expenditure in adipose tissue and skeletal muscle. Thus, we propose that bile acids activated by $B A$ serve as ligands for TGR5-mediated regulation of energy expenditure through PPAR $\alpha$ activation.

In summary, deletion of $A \operatorname{tg} 7$ in $\mathrm{CD}_{11 \mathrm{c}^{+}}$cells alters the composition of commensal bacteria, which leads to increased insulin production in serum and $\beta$-oxidation in adipose tissues and finally to protection of the host from obesity. Our discovery of the expansion of $B A$ in the gut of $A \operatorname{tg} 7^{\Delta \mathrm{CD} 11 \mathrm{c}}$ mice suggests that commensal bacteria may be interlinked between autophagy deficiency and lean phenotypes. Although further studies are required to determine the efficiency of $B A$ on diverse combinations of genetic and environment factors, our finding suggest that $B A$ may be a potent tool for metabolic diseases such as diabetes and obesity.

\section{METHODS}

\section{Ethics statement}

All animal experiments were approved by the Institutional Animal Care and Use Committee of the Asan Biomedical Research Center (Approval no: PN 2014-13-069). All experiments were performed under anesthesia with a mixture of ketamine $\left(100 \mathrm{mg} \mathrm{kg}^{-1}\right)$ and xylazine $\left(20 \mathrm{mg} \mathrm{kg}^{-1}\right)$, and all efforts were made to minimize suffering.

\section{Mice and bacteria strains}

C57BL/6 (B6), and CD11c-Cre, Villine-Cre, and LysM-Cre mice were purchased from Charles River Laboratories (Orient Bio, Sungnam, Korea) and Jackson Laboratory (Bar Harbor, $\mathrm{ME}$ ), respectively. $\operatorname{Atg} 7^{\mathrm{f} / \mathrm{f}}$ mice were kindly provided by $\mathrm{Dr}$ Komatsu (Tokyo Metropolitan Institute of Medical Science, Japan). All mice were maintained under specific pathogen-free 
conditions in the animal facility at the Asan Biomedical Research Center (Seoul, Korea) where they received sterilized food and water ad libitum. B. acidifaciens (JCM10556) and B. sartorii (JCM17136) used in this study were purchased from the Japan Collection of Microorganisms (JCM) at RIKEN BioResource Center.

\section{4 pyrosequencing analysis}

cDNA was extracted from feces using QIAamp DNA stool mini kits (Qiagen, Valencia, CA). PCR amplification was performed using primers targeting the $\mathrm{V} 1$ to $\mathrm{V} 3$ regions of the $16 \mathrm{~S}$ rRNA gene with extracted cDNA. For bacterial amplification, we used the barcoded primers of 9F (5'-CCTATCCC CTGTGTGCCTTGGCAGTC-TCAG-AC-AGAGTTTGATC MTGGCTCAG-3'; underlined sequence indicates the target region primer) and 541R (5'-CCATCTCATCCCTGCGTGT CTCCGAC-TCAG-X-AC-ATTACCGCGGCTGCTGG-3'; "X" indicates the unique barcode for each subject) (http://oklbb.ezbiocloud.net/content/1001). The amplifications were done under the following conditions: initial denaturation at $95^{\circ} \mathrm{C}$ for $5 \mathrm{~min}$, followed by 30 cycles of denaturation at $95^{\circ} \mathrm{C}$ for $30 \mathrm{~s}$, primer annealing at $55^{\circ} \mathrm{C}$ for $30 \mathrm{~s}$, and extension at $72^{\circ} \mathrm{C}$ for $30 \mathrm{~s}$, with a final elongation at $72^{\circ} \mathrm{C}$ for $5 \mathrm{~min}$. The amplified products were purified with the QIAquick PCR purification kit (Qiagen). Equal concentrations of purified products were pooled together, and short fragments (non-target products) were removed with an AMPure bead kit (Agencourt Bioscience, Beverly, MA). The quality and product size were assessed on a Bioanalyzer 2100 (Agilent, Palo Alto, CA) using a DNA 7500 chip. Mixed amplicon sequencing was done by by emulsion PCR and then deposited on picotiter plates. The sequencing was carried out at Chunlab (Seoul, Korea) on a GS Junior Sequencing System (Roche, Branford, CT) according to the manufacturer's instructions. Pyrosequencing data analysis was performed as previously described. ${ }^{45}$

\section{CE-TOF-MS measurement}

We performed a quantitative analysis of charged metabolites by CE-TOF-MS as described previously with slight modification. ${ }^{46}$ In brief, we disrupted $10 \mathrm{mg}$ of freeze-dried fecal samples using 3-mm zirconia-silica beads (BioSpec Products, Bartlesville, OK) and homogenized them with $400 \mu \mathrm{l}$ of $\mathrm{MeOH}$ containing $20 \mu \mathrm{M}$ each of methionine sulfone (Wako, Osaka, Japan) for cations, and MES (Dojindo, Kumamoto, Japan) and CSA (D-Camphol-10-sulfonic acid; Wako) for anions as internal standards. Then, $200 \mu \mathrm{l}$ of de-ionized water and $500 \mu \mathrm{l}$ of chloroform were added. After vigorous shaking using Shakemaster neo (Bio Medical Science, Tokyo, Japan) at 1,500 r.p.m. for $10 \mathrm{~min}$, the solution was centrifuged at 4,600 $\mathrm{g}$ for $15 \mathrm{~min}$ at $4{ }^{\circ} \mathrm{C}$ and filtered through a Millipore 5000-Da cutoff filter (Millipore, Billerica, MA) to remove proteins. The filtrate was lyophilized and dissolved in $25 \mu \mathrm{l}$ of water containing $200 \mu \mathrm{m}$ each of 3-aminopyrrolidine (Sigma-Aldrich, St. Louis, MO) and trimesate (Wako) as reference compounds. All CE-TOF-MS experiments were performed using Agilent Technologies equipment: a CE capillary electrophoresis system, a G3250AA LC/ MSD TOF system, an 1100 series binary HPLC pump, a G1603A CE-MS adapter, and a G1607A CE-ESI-MS sprayer kit. To identify peak annotation and quantification, data were processed using in-house software (MasterHands). ${ }^{47}$

\section{Gas chromatography mass spectrometry measurement}

Organic acid concentrations of feces were determined using a GC-mass spectrometer. ${ }^{48}$ In brief, aliquots $(80 \mu \mathrm{l})$ of ether extracts of feces were mixed with $16 \mu \mathrm{l} \mathrm{N}$-tert-butyldimethylsilyl- $N$ methyltrifluoroacetamide. The vials were sealed tightly, heated at $80^{\circ} \mathrm{C}$ for $20 \mathrm{~min}$ in a water bath, and then left at room temperature for $48 \mathrm{~h}$ for derivatization. The derivatized samples were run through a $6890 \mathrm{~N}$ Network GC System (Agilent Technologies) equipped with HP-5MS column $(0.25 \mathrm{~mm} \times 30 \mathrm{~m} \times 0.25 \mu \mathrm{m})$ and a 5973 Network Mass Selective Detector (Agilent Technologies). Pure helium (99.9999\%) was used as carrier gas and delivered at a flow rate of $1.2 \mathrm{ml} \mathrm{min}^{-1}$. The head pressure was set at $97 \mathrm{kPa}$ with a split at 20:1. The inlet and transfer line temperatures were 250 and $260^{\circ} \mathrm{C}$, respectively. The temperature program was used as follows: $60^{\circ} \mathrm{C}(3 \mathrm{~min}), \quad 60-120^{\circ} \mathrm{C}\left(5^{\circ} \mathrm{C}\right.$ per minute), $120-300{ }^{\circ} \mathrm{C}\left(20^{\circ} \mathrm{C}\right.$ per minute). Then, $1 \mu \mathrm{l}$ of each sample was injected with a runtime of $30 \mathrm{~min}$. Organic acid concentrations were quantified by comparing their peak areas with standards.

\section{Measurement of GLP-1}

Blood samples were taken from control and $B A$-fed mice, and then centrifuged for $30 \mathrm{~min}$ at $1,800 \mathrm{~g}$ at $4{ }^{\circ} \mathrm{C}$. DPP-4 inhibitor was added, and GLP-1 concentrations were determined using the GLP-1 ELISA kit (Shibayagi, Gunma, Japan).

\section{Measurement of DPP-4}

The DPP- 4 levels were determined as previously described. ${ }^{49}$ In brief, wild-type B6 mice were orally administered $B A\left(5 \times 10^{9}\right.$ CFU per $100 \mu \mathrm{l})$ or their culture supernatants $(100 \mu \mathrm{l}$ per head) or culture medium alone with the DPP-4 inhibitor sitagliptin (40 mg per mouse; Merck Sharp Dohme and Chibret Laboratories, Rahway, NJ) after fasting for $6 \mathrm{~h}$ and then given glucose $30 \mathrm{~min}$ later. After $15 \mathrm{~min}$, intestinal epithelial cells of the ileum were taken from pre-treated mice, and washed with PBS to remove luminal contents. The mucus was removed by gentle scraping, and epithelium was chopped by scissor into 1$2 \mathrm{~mm}$ lengths and placed in $1 \mathrm{ml}$ of PBS. The minced tissues were spun down by centrifugation $\left(6,000 \mathrm{~g}, 4^{\circ} \mathrm{C}, 5 \mathrm{~min}\right)$, and then $50 \mu$ lof the supernatant was incubated with kit reagents for $2 \mathrm{~h}$ at $37^{\circ} \mathrm{C}$ by DPP-4 Glo protease assay (Promega, Madison, WI). The DPP-4 activity was calculated with the value of control sample in the absence of sitagliptin.

\section{Statistics}

GraphPad Prism software (GraphPad, La Jolla, CA) was used for statistical analysis. Significant differences between two groups were analyzed with two-tailed paired $t$-test or MannWhitney $t$-test. Multiple groups were analyzed by two-way ANOVA followed by Bonferroni post-hoc test $\left({ }^{\star} P<0.05 ;{ }^{\star *} P<0.01 ;{ }^{* *} P<0.001\right)$. 
SUPPLEMENTARY MATERIAL is linked to the online version of the paper at http://www.nature.com/mi

\section{ACKNOWLEDGMENTS}

We thank Drs Kim and Woo, Animal Imaging Center, Asan Institute for Life Sciences (Seoul, Korea), for assistance with MRI analysis, Drs Sato and Kiyono, The Institute of Medical Science, University of Tokyo (Japan), for assistance with the germ-free mice experiments and helpful comments. This work was supported by the Korean Healthcare Technology R\&D Project, Ministry for Health, Welfare and Family Affairs, Republic of Korea HI12C06870000 (A120770) and HI13C0016, and the National Research Foundation of Korea (NRF) funded by the Ministry of Science, ICT \& Future Planning (MSIP) (2010-0029133).

\section{DISCLOSURE}

The authors declared no conflict of interest.

c) 2017 Society for Mucosal Immunology

\section{REFERENCES}

1. Kopelman, P.G. Obesity as a medical problem. Nature 404, 635-643 (2000).

2. Zhang, X., Zhang, G., Zhang, H., Karin, M., Bai, H. \& Cai, D. Hypothalamic IKKbeta/NF-kappaB and ER stress link overnutrition to energy imbalance and obesity. Cell 135, 61-73 (2008).

3. Kuma, A. et al. The role of autophagy during the early neonatal starvation period. Nature 432, 1032-1036 (2004).

4. Levine, B., Mizushima, N. \& Virgin, H.W. Autophagy in immunity and inflammation. Nature 469, 323-335 (2011).

5. Klionsky, D.J. The autophagy connection. Dev. Cell 19, 11-12 (2010).

6. Singh, R. et al. Autophagy regulates lipid metabolism. Nature 458, 1131-1135 (2009).

7. Yang, L., Li, P., Fu, S., Calay, E.S. \& Hotamisligil, G.S. Defective hepatic autophagy in obesity promotes ER stress and causes insulin resistance. Cell Metab. 11, 467-478 (2010).

8. Gao, Z. et al. Butyrate improves insulin sensitivity and increases energy expenditure in mice. Diabetes 58, 1509-1517 (2009).

9. Kim, K.H. et al. Autophagy deficiency leads to protection from obesity and insulin resistance by inducing Fgf21 as a mitokine. Nat. Med. 19, 83-92 (2013).

10. Delzenne, N.M., Neyrinck, A.M., Backhed, F. \& Cani, P.D. Targeting gut microbiota in obesity: effects of prebiotics and probiotics. Nat. Rev. Endocrinol. 7, 639-646 (2011).

11. Ley, R.E., Backhed, F., Turnbaugh, P., Lozupone, C.A., Knight, R.D. \& Gordon, J.I. Obesity alters gut microbial ecology. Proc. Natl. Acad. Sci. USA 102, 11070-11075 (2005).

12. Ley, R.E., Turnbaugh, P.J., Klein, S. \& Gordon, J.I. Microbial ecology: human gut microbes associated with obesity. Nature 444, 1022-1023 (2006).

13. Vijay-Kumar, M. et al. Metabolic syndrome and altered gut microbiota in mice lacking Toll-like receptor 5. Science 328, 228-231 (2010).

14. Chikayama, E. et al. Statistical indices for simultaneous large-scale metabolite detections for a single NMR spectrum. Anal. Chem. 82, 16531658 (2010).

15. Ridaura, V.K. et al. Gut microbiota from twins discordant for obesity modulate metabolism in mice. Science 341, 1241214 (2013).

16. Backhed, F. et al. The gut microbiota as an environmental factor that regulates fat storage. Proc. Natl. Acad. Sci. USA 101, 15718-15723 (2004).

17. Watanabe, M. et al. Bile acids induce energy expenditure by promoting intracellular thyroid hormone activation. Nature 439, 484489 (2006).

18. Stepanov, V., Stankov, K. \& Mikov, M. The bile acid membrane receptor TGR5: a novel pharmacological target in metabolic, inflammatory and neoplastic disorders. J. Recept Signal Transduct Res. 33, 213-223 (2013).

19. Drucker, D.J. \& Nauck, M.A. The incretin system: glucagon-like peptide-1 receptor agonists and dipeptidyl peptidase- 4 inhibitors in type 2 diabetes. Lancet 368, 1696-1705 (2006).
20. Ahren, B. \& Schmitz, O. GLP-1 receptor agonists and DPP-4 inhibitors in the treatment of type 2 diabetes. Horm. Metab. Res. 36, 867-876 (2004).

21. Katsuma, S., Hirasawa, A. \& Tsujimoto, G. Bile acids promote glucagonlike peptide-1 secretion through TGR5 in a murine enteroendocrine cell line STC-1. Biochem. Biophys. Res. Commun. 329, 386-390 (2005).

22. Sato, H. et al. Anti-hyperglycemic activity of a TGR5 agonist isolated from Olea europaea. Biochem. Biophys. Res. Commun. 362, 793-798 (2007).

23. Miyamoto, Y. \& Itoh, K. Bacteroides acidifaciens sp. nov., isolated from the caecum of mice. Int. J. Syst. Evol. Microbiol. 50 (Pt 1), 145-148 (2000).

24. Ott, S.J. et al. Reduction in diversity of the colonic mucosa associated bacterial microflora in patients with active inflammatory bowel disease. Gut 53, 685-693 (2004).

25. Tsuda, M. et al. Prior stimulation of antigen-presenting cells with Lactobacillus regulates excessive antigen-specific cytokine responses in vitro when compared with Bacteroides. Cytotechnology 55, 89-101 (2007).

26. Yanagibashi, T, Hosono, A, Oyama, A, Tsuda, M, Hachimura, S \& Takahashi, $Y$ et al. Bacteroides induce higher IgA production than Lactobacillus by increasing activation-induced cytidine deaminase expression in B cells in murine Peyer's patches. Biosci. Biotechnol. Biochem. 73, 372-377 (2009).

27. Yanagibashi, T. et al. IgA production in the large intestine is modulated by a different mechanism than in the small intestine: Bacteroides acidifaciens promotes IgA production in the large intestine by inducing germinal center formation and increasing the number of $\mathrm{IgA}^{+} \mathrm{B}$ cells. Immunobiology $\mathbf{2 1 8}$, 645-651 (2013).

28. Spor, A., Koren, O. \& Ley, R. Unravelling the effects of the environment and host genotype on the gut microbiome. Nat. Rev. Microbiol. 9, 279-290 (2011).

29. Turnbaugh, P.J., Backhed, F., Fulton, L. \& Gordon, J.I. Diet-induced obesity is linked to marked but reversible alterations in the mouse distal gut microbiome. Cell Host Microbe. 3, 213-223 (2008).

30. Murphy, E.F. et al. Composition and energy harvesting capacity of the gut microbiota: relationship to diet, obesity and time in mouse models. Gut 59, 1635-1642 (2010).

31. Fleissner, C.K., Huebel, N., Abd El-Bary, M.M., Loh, G., Klaus, S. \& Blaut, M. Absence of intestinal microbiota does not protect mice from dietinduced obesity. Br. J. Nutr. 104, 919-929 (2010).

32. Gauffin Cano, P., Santacruz, A., Moya, A. \& Sanz, Y. Bacteroides uniformis CECT 7771 ameliorates metabolic and immunological dysfunction in mice with high-fat-diet induced obesity. PLoS One 7, e41079 (2012).

33. Cooney, R. et al. NOD2 stimulation induces autophagy in dendritic cells influencing bacterial handling and antigen presentation. Nat. Med 16, 9097 (2010).

34. Homer, C.R., Richmond, A.L., Rebert, N.A., Achkar, J.P. \& McDonald, C. ATG16L1 and NOD2 interact in an autophagy-dependent antibacterial pathway implicated in Crohn's disease pathogenesis. Gastroenterology 139, 1630-1641 (2010).

35. Furusawa, Y. et al. Commensal microbe-derived butyrate induces the differentiation of colonic regulatory T cells. Nature 504, 446-450 (2013).

36. Tilg, H. \& Kaser, A. Gut microbiome, obesity, and metabolic dysfunction. J. Clin. Invest. 121, 2126-2132 (2011).

37. Lefebvre, P., Chinetti, G., Fruchart, J.C. \& Staels, B. Sorting out the roles of PPAR alpha in energy metabolism and vascular homeostasis. J. Clin. Invest. 116, 571-580 (2006).

38. Fu, J. et al. Oleylethanolamide regulates feeding and body weight through activation of the nuclear receptor PPAR-alpha. Nature 425, 90-93 (2003).

39. Tsuchida, A. et al. Peroxisome proliferator-activated receptor (PPAR)alpha activation increases adiponectin receptors and reduces obesity-related inflammation in adipose tissue: comparison of activation of PPARalpha, PPARgamma, and their combination. Diabetes 54, 3358-3370 (2005).

40. Kim, B.H et al. Phenotype of peroxisome proliferator-activated receptoralpha(PPARalpha)deficient mice on mixed background fed high fat diet. J. Vet. Sci. 4, 239-244 (2003).

41. Ribet, C. et al. Peroxisome proliferator-activated receptor-alpha control of lipid and glucose metabolism in human white adipocytes. Endocrinology 151, 123-133 (2010).

42. Ridlon, J.M., Kang, D.J. \& Hylemon, P.B. Bile salt biotransformations by human intestinal bacteria. J. Lipid Res. 47, 241-259 (2006). 


\section{ARTICLES}

43. Sayin, S.I. et al. Gut microbiota regulates bile acid metabolism by reducing the levels of tauro-beta-muricholic acid, a naturally occurring FXR antagonist. Cell Metab. 17, 225-235 (2013).

44. Tsuboyama-Kasaoka, N. et al. Taurine (2-aminoethanesulfonic acid) deficiency creates a vicious circle promoting obesity. Endocrinology 147, 3276-3284 (2006).

45. Lim, Y.W. et al. Assessment of soil fungal communities using pyrosequencing. J. Microbiol. 48, 284-289 (2010).

46. Mishima, E. et al. Alteration of the intestinal environment by lubiprostone is associated with amelioration of adenine-Induced CKD. J. Am. Soc. Nephrol. 26, 1787-1794 (2015).
47. Sugimoto, M, Wong, DT, Hirayama, A, Soga, T. \& Tomita, M. Capillary electrophoresis mass spectrometry-based saliva metabolomics identified oral, breast and pancreatic cancer-specific profiles. Metabolomics 6, 78-95 (2010).

48. Sannasiddappa, T.H., Costabile, A., Gibson, G.R. \& Clarke, S.R. The influence of Staphylococcus aureus on gut microbial ecology in an in vitro continuous culture human colonic model system. PLoS One 6, e23227 (2011).

49. Waget, A. et al. Physiological and pharmacological mechanisms through which the DPP-4 inhibitor sitagliptin regulates glycemia in mice. Endocrinology 152, 3018-3029 (2011). 